IRA-International Journal of Education \&

Multidisciplinary Studies

QUARTERLY

ISSN 2455-2526; Vol.16, Issue 03 (July-Sep, 2020)

Pg. no. 165-170.

Institute of Research Advances

https://research-advances.org/index.php/IJEMS

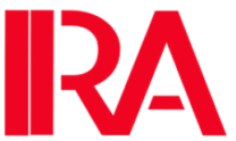

\title{
The Study of Chinese to English (C-E) Translation of Chinese Network Fantasy Novel from the Perspective of Eco-translatology: A Case Study on Battle Through the Heavens
}

\author{
Zhang Qianting \\ Academy of Literature, Xi'an Technological University, Xi'an, 710021 PRC China.
}

Type of Work: Peer-Reviewed

DOl: http://dx.doi.org/10.21013/jems.v16.n3.p5

How to cite this paper:

Qianting, Z. (2020). The Study of Chinese to English (C-E) Translation of Chinese Network Fantasy Novel from the Perspective of Eco-translatology: A Case Study on Battle Through the Heavens. IRA International Journal of Education and Multidisciplinary Studies (ISSN 2455-2526), 16(3), 165-170. DOI: http://dx.doi.org/10.21013/jems.v16.n3.p5

(C) Institute of Research Advances.

This work is licensed under a Creative Commons Attribution-NonCommercial 4.0 International License subject to a proper citation to the publication source of the work.

Disclaimer: The scholarly papers as reviewed and published by the Institute of Research Advances (IRA) are the views and opinions of their respective authors and are not the views or opinions of the IRA. The IRA disclaims of any harm or loss caused due to the published content to any party.

Institute of Research Advances is an institutional publisher member of Publishers International Linking Association Inc. (PILA-CrossRef), USA. The institute is an institutional signatory to the Budapest Open Access Initiative, Hungary advocating the open-access of scientific and scholarly knowledge. The Institute is a registered content provider under Open Access Initiative Protocol for Metadata Harvesting (OAI-PMH).

The journal is indexed \& included in WorldCat Discovery Service (USA), CrossRef Metadata Search (USA), WorldCat (USA), OCLC (USA), Open J-Gate (India), EZB (Germany) Scilit (Switzerland), Airiti (China), Bielefeld Academic Search Engine (BASE) of Bielefeld University, Germany, PKP Index of Simon Fraser University, Canada. 


\begin{abstract}
Taking the English version of Dou Po Cang Qiong as the research object, guided by Hu Gengshen's eco-translatology theory, the study analyzes how the translator adapted to the eco-environment of the C-E translation. The conclusions are as follows: the translator adapted to the eco-environment by adding logical connectors, taking omit means, combining sentences, paying attention to cultural-loaded words, highlighting or obscuring cultural information, and adjusting the information density. The translator's strategies can effectively convey the features of Chinese network fantasy novels which may help other translators when they translate similar genre novels.
\end{abstract}

Key Words: Eco-translatology; Dou Po Cang Qiong; holistic adaption and selection

\title{
1. Introduction
}

Stepping into the $21^{\text {st }}$ century, the network fantasy novel in China is welcomed by overseas readers. In the early ten years in $21^{\text {st }}$ century, some ethnic Chinese began to translate Wuxia novels in Spcent. However, they found that fantasy novels were much more welcomed by western readers. In 2010, Southeast Asian Book Publisher began to purchase the copyright more than hundreds per year. In 2014, the first C-E translation of the literature website calls Wuxiaworld was established by Lai Jingping. Then lots of overseas Chinese literature websites emerged from 2015. (Wang Rui,2019) ${ }^{1}$ Numerous foreigner became crazy about these Chinese network fantasy novels, and they also established some hot topics in Reddit and Quora.

This paper is to study the English version of the Chinese network fantasy novel from the perspective of eco-translatology, taking the English version of Dou Po CangQiong(Battle Through the Heavens) as an example. This paper attempts to summarize and analyze some of the principles and strategies that will be useful for the translation of fantasy novels.

\section{Literature Review}

\subsection{Previous Studies of Eco-translatology in China and abroad}

Eco-translatology is the first translation theory initiated by Chinese scholars at the beginning of the $21^{\text {st }}$ century. As an ecological approach in translation studies from ecological perspectives, it involves two disciplines, ecology and translatology. Eco-translatology focuses on the integrity of translational ecology, describes the relationship between translators and translational eco-environment, and focuses on the translator's living circumstances and translation ability development.

Newmark (1998) divided cultural interventions into five categories, with ecological intervention ranking the first. Warren (1989) proposes that translation is a cognitive and survival mode. David Katan further clarified and refined the classification of translational ecological culture in 1999. Cronin (2006) has set up the theoretical foundation for translation ecology. He put forward the item of translation ecology and suggested that a healthy and harmonious balance should be attained among the translation of different languages in his work Translation and Globalization. 
In the 21st century, many international translators began to follow and participate in the study of Eco-translatology, including Edwin Gentzler (2012), Kirsten Malmkjear (1998), Marry Snell Hornby (2004), Douglas Robinson (2016), etc.

In 2001, professor Hu Gengshen presents a paper titled "An Initial Exploration into an Approach to Translation as Adaptation and Selection" at the 3rd FIT Translators Forum, introducing Darwin's evolution principles into the translation field and defining the translation process as the translator's adaptation and selection in the translational eco-environment. This is a prologue to the study of eco-Translatology. (Hu Gengshen,2004) ${ }^{2}$

In 2008, Professor $\mathrm{Hu}$ Gengshen published a monograph and mainly expatiated the basic connotation, background, current situation, limitation and deficiency of the existing research and development space of the future research on eco-translatology. (Hu Gengshen, 2008:11-15) ${ }^{3}$

\subsection{Status of Network Literature Website and Dou Po Cang Qiong}

According to the analysis of the White Paper on Chinese Internet Literature Going to Abroad in 2019, and the network reader mostly coming from Europe and America. The ratio of students is $52.9 \%$ while nearly $90 \%$ of readers are male. In terms of the geographical distribution of the readers, the highest one is Europe which accounts for $29.8 \%$, and the second is North America which is $27.7 \%$.

Dou Po Cang Qiong (Battle Through the Heavens) was written by Li Hu from 2009. The click rate of it was more than $150,856,700$ time and the total recommended by the reader amounted to $6,699,600$ times. This book was also the champion in the list of online novels. (Chen Xiaochun, 2018:21-22) $)^{4}$

\section{Analyze of Battle through the Heavens from the perspective of Eco-translatology Theory}

The degree of holistic adaptation and selection is the criterion for evaluating the quality of a translated work. It includes three reference values: the translator's quality, reader's feedback, and the degree of multi-dimensional transformations. Hu's eco-translatology describes the translation method as a three-dimensional transformation. Based on his translation principle, in the process of translating the translator focuses on transformation from linguistic, communicative, and cultural dimensions. This paper will analyze Battle Through the Heavens from the perspective of the multi-dimensional transformation.

\subsection{The Linguistic Dimension}

Linguistic dimension means that the translator adapts to the selection of language form in the translation process. The great differences between English and Chinese in the form of language expression determine their differences in language expression.

In terms of the language features of Chinese and English, English pays attention to hypotaxis and the Chinese pays attention to parataxis. Hypotaxis means that words or clauses need to be connected by linguistic form to express grammatical meaning and logical relations. The most common form of language is associated with words. Parataxis prefers to make people understand the meaning of words 
through context. (Lian Shuneng,2010) ${ }^{5}$ When we translate Chinese sentences into English, we need to pay more attention to the invisible logic relations.

\section{Example 3-1}

Source Text:非常欣赏萧炎这幅震撼中夹杂着期盼与狂喜的神色，老者拓着胡子想了片刻, 又上下打量了一番, 方才似乎有些为难的叹道: “虽然只是勉强够格, 不过谁让我欠你一个人情 啊, 唉, 罢了, 就当是还人情债吧...” ( $\mathrm{Li} \mathrm{Hu}, 2009: 9)^{6}$

Target Text: Enjoying the shocked yet excited expression that Xiao Yan showed, the elder stroked his beard slowly. After looking over Xiao Yan for a few more seconds, he finally said with some helplessness: "Even though you barely cut, I owe you a favor. Hah, whatever, I'll let this count as the favor returned..." (KongXuesong, 2015:9)

In the examples above, the translator uses some conjunctions such as "and", "after" and "finally" in the English sentences. Thus the target language readers may better understand the logical meaning of these sentences.

Chinese tend to use phrases while English tend to use complex long sentence. Sometimes, the translator needs to omit or add some words to make the sentence readable.

Example 3-2

Source Text: 尝到甜头, 少年并未就此罢手, 双目依旧紧闭, 指尖的手印, 纹丝不动, 沉神 凝气，保持着最佳的修炼状态，继续贪婪的吸取着青色液体中的温和能量。( Li Hu, 2009:15)

Target Text: After confirming his success, the young man didn't stop there. He still had his eyes shut tight and kept his hands in the same position. He didn't even budge and maintained his maximally efficient position as he greedily sucked up the energy within the green liquid. (Kong Xuesong,2015:15)

\subsection{The Cultural Dimension}

Cultural transformation refers to the translator's cultural awareness in the process of translation. $\mathrm{He} / \mathrm{she}$ recognizes that translation is a cross-language and intercultural communication process, and pays attention to overcoming obstacles caused by cultural differences to ensure the smooth development of information exchange. Therefore, the translator as the subject should have better cultural awareness, understand the cultural norms, be familiar with the local customs, to make a full comprehension of the source language.

Nida also classifies cultural factors into five categories: ecological culture, social culture, material culture, religious culture, and linguistic culture. Here we will focus on ecological culture and social culture-loaded words. ( Nida, 1993:91) ${ }^{7}$

The translator uses three different strategies to translate the names of places and the typical fantasy nouns of the source text. For the first type, he uses a transliteration method to maintain the Pinyin of the proper names, such as Wutan City as 乌坦城 and Qi Gathering Pill as 聚气散. A literal translation of some typical fantasy nouns such as Six Joint Body Flowing Ruler as 六合游身尺 and 
Magic Beast Mountain Range as 魔兽山脉. The translator also adopts the selected translation strategy for some fantasy words in this novel, such as Heavenly Flame as 异火. This word in the source text has two different meanings: one is something strange and dangerous, and the other is holy and heavenly. For the sake of being better understood by the target readers, the translator chooses the second meaning of this word.

One of the main difficulties of translating social culture-loaded words lies in the transformation of the source text custom and the target text custom. Though this novel is fiction, those institutions and appellations still can be seen as sociocultural-loaded words.

Example 3-3

Source Text: 三十年河东, 三十年河西，莫欺少年穷。 (Li Hu,2009:35)

Target Text: Everything is constantly changing, don' t you dare bully me because I'm poor now. (Kong Xuesong,2015:35)

In this example, the author uses a famous quote in the History of the Scholars, and the translator simplifies it into "Everything is constantly changing", which is easy to understand and it may be largely acceptable by foreigners.

\subsection{The Communication Dimension}

Communicative transformation refers to the translator's focus on the level of communication. It stresses the transformation in language information and cultural connotation, and whether the communicative intentions in the original text are reflected.

Example 3-4

Source Text: 说完, 也不理会那俏脸冰寒的纳兰嫣然, 豁然转身, 快步行到桌前, 奋笔疾书! (Li Hu,2009:37)

Target Text: After saying that, Xiao Yan ignored the frozen face of Yanran and turned around. Quickly walking forward to a table, he took out a paper and started to write! (Kong Xuesong,2015:37)

The use of four-character also enhances the momentum and speeds up the rhythms of language. At the same time, in order to achieve the communication function of those words, the translator simplifies those four-character words into simple sentences.

\section{Enlightenment on translating of Network Fantasy Work}

Based on the analysis of the English translation of The Three-body Problem from the perspective of ecological translatology, the author draws inspiration from the translation of fantasy literature, which can provide a reference for the translation of fantasy literature.

Firstly, the eco-environment of the translation activity is restricted by the source language and fantasy text. Secondly, the translator adapted to the eco-environment by adding logical connectors, taking omit means, combining sentences, paying attention to cultural-loaded words, highlighting or 
obscuring cultural information, and adjusting the information density. Thirdly, the translator's strategies can effectively convey the features of Chinese network fantasy novels which may help other translators when they translate similar genre novels.

\section{References}

[1]. Wang Rui. Analysis of the English Translation and Dissemination of Chinese Online Novels from the perspective of Media-translatology [C]. Peiking University,2019.

[2]. Hu Gengshen. An Approach to Translation as Adaptation and Selection [C].Wuhan: Hubei Education Press,2004:134.

[3]. Hu Gengshen. Eco-translatology:A Primer [J].Chinese Translators Journal,2008,29(06):11-15.

[4]. Chen Xiaochun. Chinese Web Fictions Going Global from the perspective of Reader's Response---A Translation Study of Battle through the Heavens[C]. Fujian Normal University,2018:21-22.

[5]. Lian Shuneng. Contrastive Studies of English and Chinese[C]. Beijing: Higher Education Press,2010.

[6]. Li Hu. Dou Po Cang Qiong [C]. Jilin Publishing Group,2009.

[7]. Nida, E.A.Language, Culture, and Translation[M].Shanghai Foreign Language Education Press,1993:91, Shanghai. 